\title{
PLANT COMMUNITIES IN ARABLE FIELDS OF THE SKIERBIESZÓW LANDSCAPE PARK
}

\author{
Marta Ziemińska-Smyk \\ University of Life Sciences in Lublin, Faculty of Agricultural Sciences in Zamość \\ 102 Szczebrzeska, 22-400 Zamość, Poland \\ e-mail:msmyk@wnr.edu.pl
}

Received: 25.09 .2008

\begin{abstract}
Floristic research on segetal communities was carried out in 2000 on arable fields in the Skierbieszów Landscape Park and its protected zone. Three communities of segetal weeds in cereal crops, and two communities of segetal weeds in root crops were separated in the arable fields of the Skierbieszów Landscape Park. The community Vicietum tetraspermae typicum commonly occurred in cereal crops on brown soils developed from loess soils. The community Echinochloo-Setarietum, which belongs to root crops, was noted in the same habitat. The greatest richness of species was found in Consolido-Brometum and Lamio Veronicetum politae, with the average of 25 species in one record. Both communities were abundant in rare segetal species which are considered to be endangered in our country: Adonis aestivalis, Euphorbia exigua, Lathyrus tuberosus, Muscari comosum, Thlaspi perfoliatum, Veronica polita, Agrostemma githago.
\end{abstract}

Key words: segetal communities, arable fields, Skierbieszów Landscape Park

\section{INTRODUCTION}

The common use of herbicides and high doses of fertilizers trigger the disappearance of many segetal communities. This concerns especially the communities growing in very poor and acid, or calcerous soil. Species distinctive for these environments disappear, and nitrophilous species thrive. Impoverished communities are formed with one or two species clearly dominating (A niol-Kwiatkowska, 1990; Trąba and Ziemińska, 2006). For a long time, naturalists have been paying attention to the necessity to retain diversity of species in segetal communities (S i c i ń s k i, 2001). M e d w e c k a - K or n a ś(1986) notes that rare species and protected species can survive only if their habitats and environments within plant communities are protected. Protection of biodiversity is easier in protected areas, such as landscape parks. Agricultural management is limited there, which gives a better opportunity to counteract the threats. The aim of this study is to characterise the diversity of species of segetal communities in cereal crops and root crops in the Skierbieszów Landscape Park and its protected zone.

The aim of the study is to separate and describe weed species in cereal crops and root crops in brown soils and rendzinas of the Skierbieszów Landscape Park and its protected zone. The research that was carried out allows to distinguish endangered and rare species of segetal flora in the investigated area. Detailed studies of segetal communities were not conducted in this area. Fragmentary studies on the plants of the Skierbieszów Landscape Park were made by Fijałkowski and Adamczyk (1990).

\section{MATERIALS AND METHODS}

Floristic research on segetal communities was carried out in 2000 on arable fields in the Skierbieszów Landscape Park and its protected zone (Fig. 2) on brown soils and rendzinas. Moreover, in May 2001 the list of segetal flora species was supplemented with typically spring species. The type and kind of soil and its agricultural usability were determined on the basis of soil-agricultural maps at a scale of 1:5000. In cereal and root crops, 110 phytosociological records were taken using the Braun-Blanquet method (1964). Species nomenclature followed Mir e k et al. (2002) and the classification of communities was based on the system proposed by M a t u s zki e w i c z (2002). The records were grouped into communities of weeds, which were subsequently put into floristic tables (Tabs 1-2). In the tables, the degree of constancy (S) and the cover coefficient (D) were calculated for specific taxons; only these species were included which reached at 


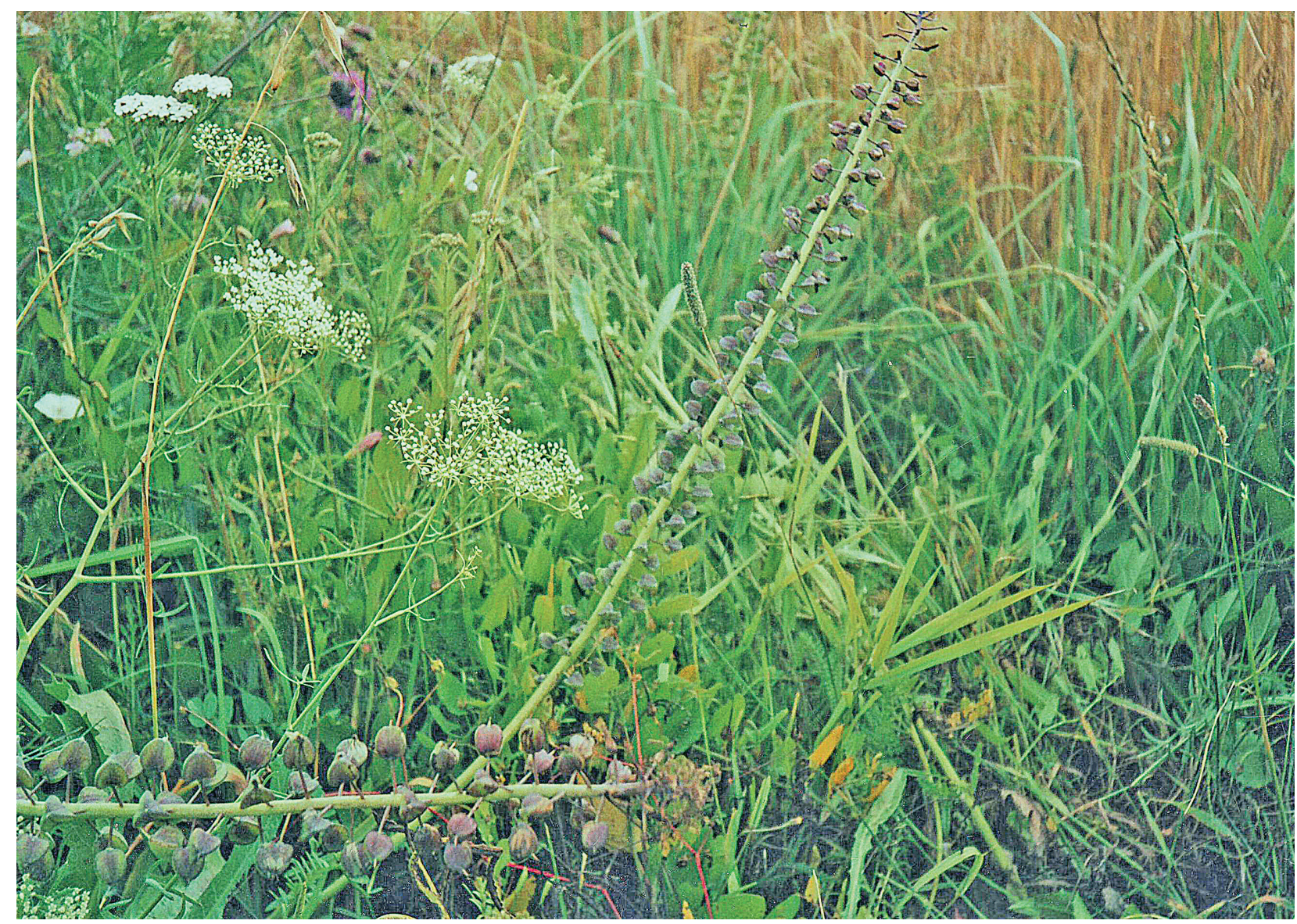

Fig. 1. Muscari comosum in cereals - rare calciphilous species.

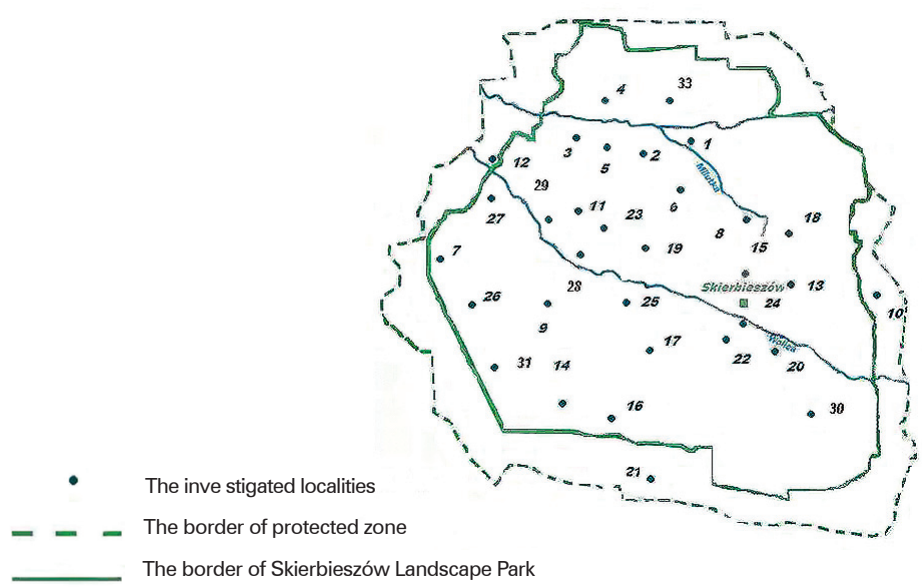

Fig. 2. 1. The list of the investigated localites:

1 - Krasniczyn, 2 - Majdan Surhowski, 3 - Surhów, 4 - Łukaszówka, 5 - Franciszków, 6 - Anielpol, 7 - Zalesie, 8 - Drewniki, 9 - Majdan Sitaniecki, 10 - Osiczyna, 11 - Orłów Murowany, 12 - Wólka Orłowska, 13 - Nowa Lipina, 14 - Chomęciska Małe, 15 - Kolonia Zrąb, 16 - Borowina Starozamojska, 17 - Pańska Dolina, 18 - Podwysokie, 19 - Sulmice, 20 - Szorcówka, 21 - Udrycze, 22 - Suchodębie, 23 - Kryniczki, 24 - Skierbieszów, 25 - Kalinówka, 26 - Krasne, 27 - Orłów Drewniany, 28 - Zabytów, 29 - Stryjów, 30 - Cieszyn, 31 - Wierzba, 32 - Stara Wieś, 33 - Czajki. 
Table 1

Floristic diversity and species richness in cereal communities in Skierbieszów Landscape Park.

\begin{tabular}{|c|c|c|c|c|c|c|c|c|}
\hline \multirow{2}{*}{$\begin{array}{l}\text { Alliance } \\
\text { Association }\end{array}$} & \multirow{2}{*}{\multicolumn{2}{|c|}{$\begin{array}{c}\text { Aperion } \\
\text { Vicietum } \\
\text { tetraspermae } \\
\text { typicum }\end{array}$}} & \multicolumn{3}{|c|}{ spicae - venti } & & \multicolumn{2}{|c|}{$\begin{array}{l}\text { Caucalidion } \\
\text { lappulae }\end{array}$} \\
\hline & & & \multicolumn{2}{|c|}{$\begin{array}{l}\text { V.t. typicum variant } \\
\text { with Apera spica-venti }\end{array}$} & & $\begin{array}{l}\text { Consolido- } \\
\text { Brometum }\end{array}$ & \multicolumn{2}{|r|}{ Avena fatua } \\
\hline Number of records & & 18 & & 13 & & 10 & & 10 \\
\hline Number of species & & 82 & & 71 & & 85 & & 66 \\
\hline $\begin{array}{l}\text { Mean number of species in } \\
\text { one record }\end{array}$ & & 22.9 & & 19.8 & & 25.9 & & 18.8 \\
\hline Soil unit & & $1,2,3 \mathrm{Bwl}^{*}$ & & 2,3 Bwl & & $3 R$ & & 3Bwl, 3R \\
\hline$\underline{\text { Soil pH }}$ & & 5.5 & & 5.4 & & 6.8 & & 5.9 \\
\hline $\begin{array}{l}\text { Constancy S, Density of } \\
\text { coverage - D }\end{array}$ & $\mathrm{S}$ & $\mathrm{D}$ & $\mathrm{S}$ & $\mathrm{D}$ & $\mathrm{S}$ & $\mathrm{D}$ & $\mathrm{S}$ & $\mathrm{D}$ \\
\hline \multicolumn{9}{|l|}{ Ch. Aperion spicae-venti } \\
\hline Apera spica-venti & $\mathrm{V}$ & 1368 & $\mathrm{~V}$ & 3750 & IV & 1170 & III & 195 \\
\hline Vicia hirsuta & IV & 419 & III & 131 & IV & 295 & III & 235 \\
\hline Consolida regalis & II & 37 & II & 19 & $\mathrm{~V}$ & 1020 & II & 10 \\
\hline Vicia tetrasperma & IV & 253 & III & 58 & III & 17 & & \\
\hline Bromus secalinus & II & 161 & II & 15 & $\mathrm{I}$ & 10 & & \\
\hline Seleranthus annuus & II & 136 & $\mathrm{I}$ & 5 & & & & \\
\hline Veronica hederifolia & & & & & II & 15 & & \\
\hline \multicolumn{9}{|l|}{ Ch.D. Caucalidion lappulae } \\
\hline Avena fatua & & & & & $\mathrm{I}$ & 6 & $\mathrm{~V}$ & 1975 \\
\hline Melandrium noctiflorum & & & & & II & 16 & $\mathrm{I}$ & 5 \\
\hline Euphorbia exigua & & & & & II & 6 & $\mathrm{I}$ & 5 \\
\hline Aethusa cynapium & & & & & $\mathrm{I}$ & 6 & & \\
\hline \multicolumn{9}{|l|}{ Ch.Centauretalia cyani } \\
\hline Centaurea cyanus & IV & 347 & IV & 462 & II & 15 & $\mathrm{~V}$ & 85 \\
\hline Vicia sativa & IV & 58 & II & 15 & III & 66 & II & 10 \\
\hline Papaver rhoeas & II & 217 & II & 300 & $\mathrm{~V}$ & 305 & II & 10 \\
\hline Anthemis arvensis & II & 11 & II & 300 & II & 60 & I & 5 \\
\hline Vicia villosa & IV & 131 & II & 18 & III & 62 & & \\
\hline \multicolumn{9}{|l|}{$\begin{array}{l}\text { Ch. Polygono- } \\
\text { Chenopodietalia }\end{array}$} \\
\hline Setaria pumila & III & 219 & III & 158 & II & 190 & $\mathrm{~V}$ & 1280 \\
\hline Echinochloa crus-galli & III & 20 & $\mathrm{I}$ & 173 & $\mathrm{I}$ & 6 & III & 30 \\
\hline Setaria viridis & $\mathrm{I}$ & 103 & $\mathrm{I}$ & 8 & $\mathrm{I}$ & 6 & II & 15 \\
\hline Veronica persica & II & 11 & II & 12 & II & 15 & III & 20 \\
\hline Polygonum aviculare & II & 17 & I & 5 & II & 11 & I & 5 \\
\hline Capsella bursa-pastoris & II & 111 & $\mathrm{I}$ & 8 & $\mathrm{I}$ & 6 & II & 10 \\
\hline Galinsoga parviflora & $\mathrm{I}$ & 30 & $\mathrm{I}$ & 8 & II & 15 & & \\
\hline Sonchus arvensis & II & 11 & $\mathrm{I}$ & 139 & $\mathrm{I}$ & 180 & & \\
\hline
\end{tabular}


cd. Table 1

\begin{tabular}{|c|c|c|c|c|c|c|c|c|}
\hline \multirow{2}{*}{$\begin{array}{l}\text { Alliance } \\
\text { Association }\end{array}$} & \multirow{2}{*}{\multicolumn{2}{|c|}{$\begin{array}{c}\text { Aperion } \\
\text { Vicietum } \\
\text { tetraspermae } \\
\text { typicum }\end{array}$}} & \multicolumn{3}{|c|}{ spicae - venti } & \multirow[b]{2}{*}{$\begin{array}{l}\text { Consolido- } \\
\text { Brometum }\end{array}$} & \multicolumn{2}{|c|}{$\begin{array}{l}\text { Caucalidion } \\
\text { lappulae }\end{array}$} \\
\hline & & & \multicolumn{2}{|c|}{$\begin{array}{l}\text { V.t. typicum variant } \\
\text { with Apera spica-venti }\end{array}$} & & & & Avena fatua \\
\hline Sonchus asper & & & II & 19 & $\mathrm{I}$ & 6 & & \\
\hline \multicolumn{9}{|l|}{ Ch.Stelarietea mediae } \\
\hline $\begin{array}{l}\text { Matricaria maritima ssp. } \\
\text { inodora }\end{array}$ & $\mathrm{V}$ & 1319 & IV & 369 & III & 30 & III & 235 \\
\hline Myosotis arvensis & IV & 183 & IV & 627 & IV & 225 & III & 25 \\
\hline Fallopia convolvulus & II & 16 & III & 158 & III & 30 & III & 285 \\
\hline Viola arvensis & IV & 64 & IV & 69 & III & 30 & III & 25 \\
\hline Stellaria media & II & 19 & II & 19 & III & 25 & II & 230 \\
\hline Galeopsis tetrahit & II & 16 & II & 15 & $\mathrm{I}$ & 55 & II & 10 \\
\hline Anagallis arvensis & III & 25 & II & 19 & IV & 85 & III & 65 \\
\hline Lapsana communis & $\mathrm{I}$ & 5 & II & 19 & $\mathrm{I}$ & 16 & & \\
\hline Sinapis arvensis & II & 14 & & & I & 5 & II & 15 \\
\hline Veronica arvensis & II & 14 & II & 12 & & & I & 5 \\
\hline Sonchus asper & II & 11 & & & & & II & 15 \\
\hline \multicolumn{9}{|l|}{ Other } \\
\hline Equisetum arvense & IV & 219 & IV & 269 & II & 11 & II & 10 \\
\hline Cirsium arvense & III & 47 & III & 62 & IV & 205 & III & 60 \\
\hline Convolvulus arvensis & II & 67 & II & 219 & IV & 455 & III & 480 \\
\hline Agropyron repens & II & 319 & III & 58 & II & 60 & $\mathrm{I}$ & 5 \\
\hline Chenopodium album & $\mathrm{I}$ & 8 & $\mathrm{I}$ & 8 & II & 60 & III & 190 \\
\hline Polygonum persicaria & $\mathrm{I}$ & 5 & $\mathrm{I}$ & 138 & $\mathrm{I}$ & 10 & II & 10 \\
\hline Stachys palustris & II & 14 & II & 308 & II & 20 & $\mathrm{I}$ & 50 \\
\hline Arenaria serpyllifolia & $\mathrm{I}$ & 3 & $\mathrm{I}$ & 5 & III & 25 & $\mathrm{I}$ & 5 \\
\hline Galium aparine & IV & 150 & III & 23 & IV & 255 & II & 250 \\
\hline Taraxacum officinale & IV & 272 & II & 185 & IV & 125 & II & 15 \\
\hline Artemisia vulgaris & III & 50 & $\mathrm{I}$ & 42 & III & 25 & II & 10 \\
\hline Medicago lupulina & $\mathrm{I}$ & 3 & $\mathrm{I}$ & 8 & III & 25 & $\mathrm{I}$ & 15 \\
\hline Plantago pauciflora & II & 19 & III & 308 & II & 15 & II & 10 \\
\hline Daucus carota & $\mathrm{I}$ & 8 & & & III & 25 & II & 10 \\
\hline Conyza canadensis & III & 22 & II & 46 & $\mathrm{I}$ & 10 & & \\
\hline Achillea millefolium & II & 39 & III & 23 & III & 25 & & \\
\hline Gnaphalium uliginosum & II & 11 & II & 12 & & & & \\
\hline Agrostis stolonifera & $\mathrm{I}$ & 103 & II & 142 & & & II & 189 \\
\hline Gypsophila muralis & II & 14 & II & 19 & & & II & 10 \\
\hline $\begin{array}{l}\text { Campanula } \\
\text { rapunculoides }\end{array}$ & & & & & II & 15 & & \\
\hline
\end{tabular}

Explanation:* Bwl-brown soil formed from loess, R - rendzinas, 1- very good wheat complex, 2 - good wheat complex, 3 - defective wheat complex, $\mathrm{Ch}$ - characteristic species. 
least once constancy II in one community. Soil samples were collected from the patches of plant communities in order to determine the $\mathrm{pH}$ of the surface layer of the soil. The results of this analysis were put in the headings of the tables (Tabs 1,2). The investigated areas are shown in Fig. 2.

\section{Characterisation of the investigated area}

The Skierbieszów Landscape Park is located in the Lublin province and occupies the eastern part of the province, called Wierzchowina Grabowiecka or 'działy Grabowieckie', which apart from Roztocze belongs to the most interesting subregions of Eastern Poland, as far as nature and landscapes are concerned. The park was set up in 1995 and includes the whole area of Skierbieszów commune and parts of the following communes: Stary Zamość, Izbica, Sitno, Grabowiec, Miączyn, Kraśniczyn, and Krasnystaw, with a total area of 35488 ha, including the protected zone 47967 ha (Fi jałk ow s k i , 1996). According to geobotanical division of the Lublin region, the area of the Skierbieszów Landscape Park belongs to the Lowland-Highland Province, Central European, Baltic Division, Central Highlands Division, Land: Lublin Highland (S z a f e r, 1959).

The areas surrounding Skierbieszów are known in geobotanical literature for beech forests on the northeast boundaries ( $\mathrm{Fi} \mathrm{jałk} \mathrm{ow} \mathrm{s} \mathrm{ki} \mathrm{and} \mathrm{A} \mathrm{d} \mathrm{a} \mathrm{m} \mathrm{c} \mathrm{z} \mathrm{y} \mathrm{k,}$ 1990). Another characteristic feature of the area is the occurrence of swards and xerothermal thickets. The arable sites of the park consisted of 145 weed species, including 40 protected species. The main branch of human activity in the investigated area is agriculture. Therefore, arable lands account for the greatest part of the Park and its protected zone. Arable lands cover almost $80 \%$ of the area (Census of Agriculture 2003) and can be found mainly in the following communes: Grabowiec, Sitno, Miączyn, whereas in the communes: Stary Zamość, Skierbieszów, Izbica, arable lands cover a smaller part of the area. The greatest area in the structure of arable lands is covered with arable soils. There are small areas of meadows and pastures. The high quality of the area for agricultural production in the landscape park (F i j a ł k o w s k i, 1990) provides great opportunities to cultivate high demand crops, such as wheat and root crops; the former takes up 66\% of the cultivated area; potatoes and beet cover slightly smaller areas (Census of Agriculture 2003).

\section{RESULTS AND DISCUSSION}

In the area of the Skierbieszów Landscape Park and its protected zone, three communities of cereal crops and two communities of root crops were distinguished. The community Vicietum tetraspermae is the most common in the investigated area. It occurred on loess soils that belong to good wheat and defective wheat complex. The $\mathrm{pH}$ of the surface layer of the soil ranged from $\mathrm{pH} 4.1$ to 7.0 (Tab. 1). The reaction of most of the analysed soil samples was acidic or slightly acidic (Obojs ki and Strą c z yńs ki, 1995).

Vicia tetrasperma occurred most frequently in the community, another species - Bromus secalinus - was found very rarely (Tab. 1).

The Vicietum tetraspermae typicum community developed mainly in winter wheat, less frequently in rye canopy. The community consisted of 82 weed species. An average of 22.9 taxons was noted in one record. Much greater floristic richness was found in an analogical community in the protected zone of Roztocze National Park (Zi e mińs k a-S m y k, 2006), where about 30 species were noted in one record. The same community that was distinguished by Skrzyczyńska in the area of 'Wysoczyzna Kaluszyńska' consisted of a smaller number of species (Skrzyczyńska and Skrajna 2004), with an average of 18 species in one record.

The analyzed community was found in the following places: Skierbieszów, Wólka Orłowska, Majdan Sitaniecki, Udrycze, Krasne, Osiczyna, Majdan Żukowski, Sulmice, Franciszków. Apera spica-venti from the group Aperion spicae-venti occurred most commonly there. Other weeds of this group (Vicia hirsuta, Vicia sativa, and Scleranthus annuus) were found rather frequently (Tab. 1). Centaurea cyanus occurred most commonly in the suborder Centauretalia cyani. There were also many weeds of the Stellarietea order (Matricaria maritima, Myosottis arvensis, Viola arvensis and Anagallis arvensis).

The Vicietum tetraspermae typicum community frequently occurs in the Lublin region ( $\mathrm{Fij} \mathrm{a} \mathrm{k} \mathrm{k} \mathrm{w-}$ s k i, 1996; K u c harc z y k, 1999; Z i e m iń s k a S m y k, 2006), and in the whole country (A n i ołK w i a t k ow s k a , 1990; S k r z y c z yń s k a , 1994). It is replaced with the community EchinochlooSetarietum in root crops (A n i o ł - K w i a t k o w s k a, 1990; K u c h a r c z y k, 1999).

Within the typical Vicia tetrasperma community, a variant was separated that occurred very frequently - Apera spica-venti, which developed in environments similar to a typical community. However, this community was very poor floristically because on the average 19.8 taxons were observed. It occurred most frequently in Majdan Skierbieszowski, Drewniki, Osiczyna, Udrycze, Pańska Dolina, Nowa Lipina and Drewniki. The species characteristic for the community had low cover coefficients and degrees of constancy (Tab. 1). The physiognomy of the community was mainly built by Apera spica-venti, with the cover coefficient of over 3800 . Other perennial species that 
Table 2

Floristic diversity and species richness in root-crops communities in Skierbieszów Landscape Park.

\begin{tabular}{|c|c|c|c|c|c|c|}
\hline \multirow{2}{*}{$\begin{array}{l}\text { Alliance } \\
\text { Association }\end{array}$} & \multicolumn{4}{|c|}{ Panico-Setarion } & \multicolumn{2}{|c|}{ Polygono-Chenopodior } \\
\hline & \multicolumn{2}{|c|}{$\begin{array}{l}\text { Echinochloo-Setarietum } \\
\text { typicum }\end{array}$} & \multicolumn{2}{|c|}{$\begin{array}{l}\text { Echinochloo-Setarietum } \\
\text { typicum variant with } \\
\text { Galinsoga parviflora }\end{array}$} & \multicolumn{2}{|c|}{$\begin{array}{l}\text { Lamio-Veronicetum } \\
\text { politae typicum }\end{array}$} \\
\hline Number of records & \multicolumn{2}{|c|}{9} & \multicolumn{2}{|c|}{7} & \multicolumn{2}{|c|}{5} \\
\hline Number of species & \multicolumn{2}{|c|}{65} & \multicolumn{2}{|c|}{49} & \multicolumn{2}{|c|}{50} \\
\hline Mean number in one record & \multicolumn{2}{|c|}{22.4} & \multicolumn{2}{|c|}{18.6} & \multicolumn{2}{|c|}{25.3} \\
\hline Soil unit & \multicolumn{2}{|c|}{$2.3 \mathrm{Bw} 1$} & \multicolumn{2}{|c|}{$2.3 \mathrm{Bw} 1$} & \multicolumn{2}{|c|}{$3 \mathrm{R}$} \\
\hline Soil pH & \multicolumn{2}{|c|}{5.4} & \multicolumn{2}{|c|}{5.6} & \multicolumn{2}{|c|}{6.8} \\
\hline Constancy - S, Density of coverage D & $\mathrm{S}$ & $\mathrm{D}$ & $\mathrm{S}$ & $\mathrm{D}$ & S & $\mathrm{D}$ \\
\hline \multicolumn{7}{|l|}{ Ch.D Panico-Setarion } \\
\hline Setaria pumila & $\mathrm{V}$ & 508 & $\mathrm{~V}$ & 28 & III & 40 \\
\hline Echinochloa crus galli & $\mathrm{V}$ & 1079 & $\mathrm{~V}$ & 1228 & & \\
\hline Spergula arvensis & II & 11 & & & & \\
\hline Scleranthus annuus & II & 11 & & & & \\
\hline \multicolumn{7}{|l|}{ Ch. D. Polygono-Chenopodion } \\
\hline Galinsoga parviflora & II & 11 & $\mathrm{~V}$ & 2250 & $\mathrm{~V}$ & 50 \\
\hline Sonchus asper & III & 211 & III & 29 & III & 37 \\
\hline Veronica persica & II & 11 & III & 21 & III & 462 \\
\hline Lamium amplexicaule & I & 5 & II & 14 & III & 27 \\
\hline Veronica polita & & & & & $\mathrm{V}$ & 600 \\
\hline Euphorbia helioscopia & & & & & I & 12 \\
\hline \multicolumn{7}{|l|}{ Ch. Polygono-Chenopodietalia } \\
\hline Chenopodium album & $\mathrm{V}$ & 333 & $\mathrm{~V}$ & 1121 & $\mathrm{~V}$ & 812 \\
\hline Stellaria media & III & 29 & IV & 639 & II & 25 \\
\hline Polygonum lapathifolium ssp.pallidum & III & 11 & I & 7 & II & 25 \\
\hline Solanum nigrum & & & & & II & 140 \\
\hline \multicolumn{7}{|l|}{ Ch. Centauretalia cyani } \\
\hline Anthemis arvensis & IV & 39 & II & 14 & II & 25 \\
\hline Centaurea cyanus & IV & 33 & I & 7 & II & 15 \\
\hline Vicia hirsuta & II & 11 & II & 14 & I & 12 \\
\hline Vicia sativa & II & 17 & & & & \\
\hline Papaver rhoeas & II & 17 & & & & \\
\hline Vicia villosa & II & 17 & & & & \\
\hline Avena fatua & & & & & III & 140 \\
\hline
\end{tabular}


cd. Table 2

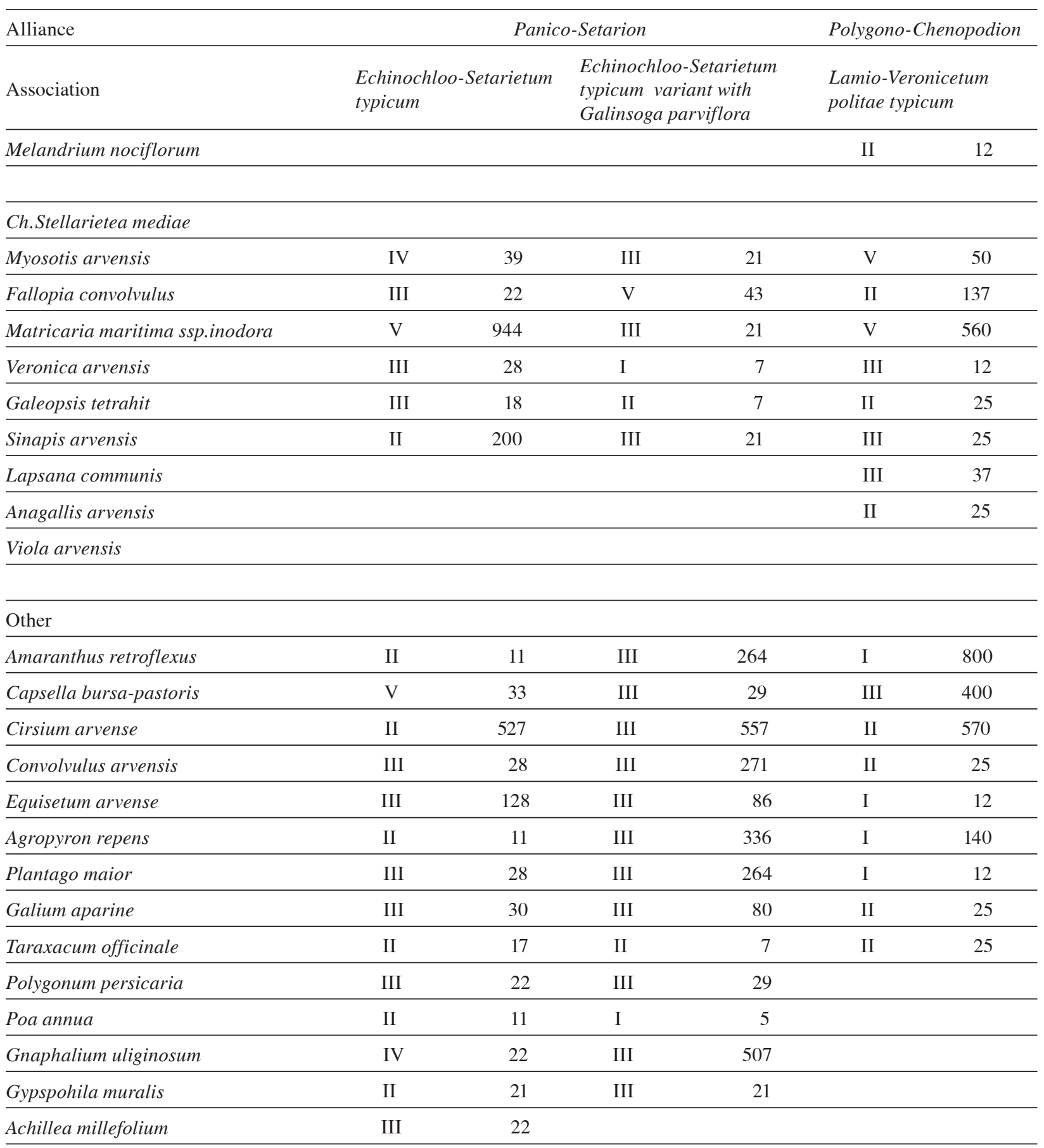


occurred frequently were Equisetum arvense, Cirsium arvense, and Agropyron repens. This community was botanically similar to an impoverished community described in Wał Trzebnicki (A n i o ł- Kw i a tk ow s$\mathrm{k} \mathrm{a}, 1990)$.

The Consolido-Brometum community that belongs, like Vicietum tetraspermae, to the Aperion community developed in the investigated area in rendzinas of the defective wheat complex. The $\mathrm{pH}$ of the surface layer of the soil was neutral - within 6.7-7.0. The community was found mainly in winter wheat canopy and was represented by 85 weed species. It was floristically rich, with an average number of 25.9 taxons in one record. The community was observed in Kryniczki, Chomęciska Małe, Borowina Starozamojska and Orłów Murowany. Among the most characteristic species, Consolida regalis was the one that was found most frequently (Tab. 1), but Bromus secalinus occurred very rarely. From the Aperion community, the following taxons were noticed: Apera spica-venti, Vicia hirsuta, and less frequently $V$. sativa. In the calciphilous Caucalidion community, attention should be paid to Melandrium noctiflorum, Agrostemma githago, Avena fatua, Euphorbia exigua, Lathyrus tuberosus, and from the remaining group - Muscari comosum. They belong to rare calciphilous species in segetal flora of our country (Fijałkowski, 1996; Siciński, 2001; W a r c h o 1 i ń s k a, 1998). Over a dozen plants of this species were found in the area of Skierbieszów Landscape Park (fallow land and adjacent arable fields in Borowina Starozamojska).

The Avena fatua community infested mainly spring crops (mixture, oats, barley) in rendzina and brown loess soils with a slightly acidic soil $\mathrm{pH}$ (Tab. $1)$. This community was floristically poor, with an average of 18.8 species in one record (66 species on average). The community was observed in the following places: Orłów Murowany, Chomęciska Małe, Kryniczki, Suchodębie, Pańska Dolina. The community had features that place it between the Caucalidion and Aperion communities. This community was dominated by Avena fatua, from the calciphilous Caucalidion community, and reached high constancy $(\mathrm{V})$ and the cover coefficient of about 1980. From the acidophilous Aperion community, Apera spica-venti and Vicia hirsuta occurred quite frequently. From the PolygonoChenopodietalia suborder, Setaria pumila was the most common. The community with similar floristic contents, described as an impoverished community from the Caucalidion community, is known from a study of W n u k et al. (1989). The association of Avena fatua in spring crops was described by H o ł d y ń s k i (1991) in Zuławy Wiślane.

The Echinochloo-Setarietum community was found in similar environments as Vicietum tetrasper- mae typicum. It occurred commonly in the area where sugar beet, beetroot, and potato were cultivated. 74 species of weeds were noticed in the community, with the average of 22.4 taxons in one record. The community was found in the following places of the Park: Zabytów, Sulmice, Udrycze, Stryjów, Cieszyn, Wierzba and Majdan Sitaniecki. The most characteristic species in the community were: Echinochloa crus-galli and Setaria pumila (Tab. 2). From the Polygono-Chenopodietalia suborder, a very important role in crop infestation was played by Chenopodium album. and Matricaria maritima ssp. indora as well as Myosotis arvensis from Stellarietea mediae.

The Echinochloo-Setarietum community commonly occurs in root crops in the Lublin region $(\mathrm{Fi}$ jałk ow ski, 1996; K u charczy k, 1999; Trąba and $\mathrm{Ziemińska,2006)}$ and in the whole country (A ni oł-Kwi a tkowska, 1990, Hołdyński, 1991, Rzymowska and Skrzyczyńska, 2007).

The variant Echinochloo-Setraietum with $\mathrm{Ga}$ linsoga parviflora had a high contribution of Galinsoga parviflora and Echinochloa crus-galli (Tab. 2). This variant differed from a typical community in the high contribution of species such as Chenopodium album and Stellaria media (Tab. 2). Phytocoenoses of this type were observed in Stara Wieś, Stryjów, Zabytów, and Czajki in potato and sugar beet canopy. There was significantly lower richness of species in the community than in a typical variant, in one phytosociological record 18.6 species of weeds were observed, with a total number of 49 species.

A community with similar floristic contents was observed by Towpasz and Barabasz-Krasny in the area of Czarnorzęki-Strzyżów Landscape Park (2006) and Skrzyczyńska and Marciniuk from Siedlce (2003).

The Lamio-Veronicetum politae community is a representative of eutrophilous alliance PolygonoChenopodion. In the area of the Park it occurred mainly in rendzinas of the defective wheat complex with neutral reaction (Tab. 2). The community occupied small areas in Kryniczki, Borowina Starozamojska and Chomęciska Małe. The total number of 49 weed species was observed in the community, with the average number of species in the relevé - 25.2 taxons. A characteristic species in the community - Veronica polita - occurred often and grew thickly ( $\mathrm{V}$ degree of constancy); the second taxon - Lamium amplexicaule - was more rarely encountered. In the community, numerous rare calciphilous species were observed such as: Euphorbia exigua, Aethusa cynapium, Melandrium noctiflorum. The physiognomy of the community was determined by Matricaria maritima ssp. indora, Chenopodium album, and Cirisium arvense 
(Tab. 2). Lamio-Veronicetum politae was described by Hołdyńs ki (1991), K u charczy k (1999) as well as T rą b a and Zi e m iń s k a (1994). This community undergoes significant changes caused by anthropopression, which result in the elimination of species with narrow ecological amplitude, such as the species characteristic for this community (Fijałk ow ski, 1996; S i c ińs ki 2001; W a r c hol ińs k a, 1998).

\section{CONCLUSIONS}

1. Three segetal communities were separated in cereal crops, in rendzinas and loess soils of the Skierbieszów Landscape Park. Two segetal communities were separated in root crops, in rendzinas and loess soils of the Skierbieszów Landscape Park.

2. Vicietum tetrsperma typicum was the most frequently found community in cereal crops in loess soils in the investigated area. The Echinochloo-Setarietum community was found in root crops on the same soils.

3. The greatest richness of species was found in Consolido-Brometum and Lamio Veronicetum politae, 25 species on the average. Both communities were abundant in rare segetal species which are considered to be endangered in our country; they were as follows: Adonis aestivalis, Veronica polita, Thlaspi perfoliatum, Euphorbia exigua, Lathyrus tuberosus, and Muscari comosum. These phytocoenoses and their habitats should be protected.

\section{REFERENCES}

Aniol-Kwiatkowska J., 1990. Zbiorowiska segetalne Wału Trzebnickiego. / Segetal communities of the Trzebnica Moraine Belt. Prace Bot. UW, 46: 1-71.

B r a u n-B l a n quet J., 1964. Pflanzensoziologie, Gründzunge der Vegetationscunde.Vien.-N.York, Springer-Verl.: $1-869$.

Census of Agriculture, 2003.

Fijałkowski D., 1996. Środowisko przyrodnicze Lubelszczyzny. / The natural environment of the Lublin region. Lubelskie Towarzystwo Naukowe: 1-88.

Fijałkowski D., Adamczyk B., 1990. Zespoły i flora projektowanego Skierbieszowskiego Parku Krajobrazowego. / The associations and flora of the planned Skierbieszów Landscape Park. UMCS, Lublin: 1-111.

Hołdyński Cz., 1991. Flora segetalna, zróżnicowanie florystyczno-ekologiczne i przemiany szaty roślinnej pól uprawnych w aktualnych warunkach agroekologicznych Żuław Wiślanych. / Segetal flora, floristic and ecological diversity and transformations of the plant cover of cultivated fields in current agro-ecological conditions of the Vistula Delta Plain. Acta Acad. Agricult. tech. Olst. Agricultura, 51: 3-50.

Ku charczyk M., 1999. Zespoły i zbiorowiska roślinne Kazimierskiego Parku Krajobrazowego. Cz. IV. Zespoły i zbiorowiska synantropijne. / Plant associations and communities of the Kazimierz Landscape Park. Part IV. Synantrophic associations and communities. Ann. Univ. Mariae Curie-Skłodowska, Sect. 44:198-212.

Matuszkiewicz W., 2002. Przewodnik do oznaczania zbiorowisk roślinnych Polski. Polskie Wydawnictwo Naukowe: 1-536.

Medwecka-Kornaś A., 1986. Ekologiczne problemy rezerwatowej ochrony roślin. / Ecological problems of plant protection in nature reserves. Acta Univ. Lodz., Folia Bot. 3: 21-35.

Mirek Z., Piękoś-Mirkowa H., Zając A., Zając M., 2002. Flowering plants and pteridophytes of Poland. A checklist.: J.: Z. Mirek (ed) Biodiversity of Poland, Vol. 1: 1-442, W. Szafer institute of Botany, Polish Akademy of Sciences.

Obojski J, Strączyński S., 1995. Odczyn i zasobność gleb Polski w makro i mikroelementy. / The $\mathrm{pH}$ and availability of macro- and micronutrients in Polish soils. Wydawnictwo IUNG Puławy: 1-40.

R z y mowska Z., Skrzy czy ńska J., 2007. Plant communites of cultivated field sof the Podlaski Przełom Bugu mesoregion. Part. 5. Root crop communities of light soils. Acta Agrobot. 60 (1): 191-205.

S i c iński J. T., 2001. Gatunkowa różnorodność biologiczna chwastów segetalnych i jej zagrożenia w Polsce. / Biological species diversity of segatal weeds and its threats in Poland. Acta Univ. Lodz., Folia Bot. 16: 72-86.

Skrzyczyńska J. 1994. Studia nad florą i zbiorowiskami segetalnymi Wysoczyzny Siedleckiej. / Studies on the flora and segetal communities of the Siedlce Upland.

Wydawnictwo Nauk WSRP, Siedlce, Rozprawy Nauk. 39: 1-145.

Skrzyczyńska J., Marciniuk J., 2003. Zbiorowiska segetalne rzędu Polygono-Chenopodietalia w granicach Siedlec. / Segetal communities of the order PolygonoChenopodietalia within the boundaries of Siedlce. Acta Sc. Pol., Biologia 2 (1-2), 19-31.

Skrzyczyńska J., Skrajna T., 2004. Zbiorowiska polne Wysoczyzny Kałuszyńskiej.,Cz. I. Zespoły zbożowe. I Vegetation of fields of the Kałuszyńska Upland. Part 1. Cereal plant associations. Fragm. Agronom. 4 (84): 33-43.

S z a fer W., 1959. Szata roślinna Polski. Polskie Wydawnictwo Naukowe: Warszawa.

Tow pas z K., B arabasz-Krasny B., 2006. Zróżnicowanie roślinności segetalnej na obszarze CzarnorzeckoStrzyżowskiego Parku Krajobrazowego. / Variations in segetal flora within the area of the Czarnorzeki-Strzyżow Landscape Park. Pamiętnik Puławski 143: 183-194.

Trąb a Cz., Zie mińsk a M., 1994. Zbiorowiska chwastów na polach uprawnych w okolicach Zamościa. Cz. II. Zbiorowiska na glebach brunatnych, bielicowych i czarnych ziemiach. / Weed communities in cultivated fields in the area of Zamość. Part 2. Communities on brown, podzolic and chernozem soils. Ann. Univ. Mariae $\mathrm{Cu}-$ rie-Skłodowska, Sect. 49 (15): 99-107. 
Trą̧ a Cz., Zi e m iń sk a - S m y k M., 2006. Różnorodność florystyczna zbiorowisk chwastów w uprawach roślin okopowych otuliny Roztoczańskiego Parku Narodowego. / Floristic diversity of weed communities in root crops of the buffer zone of the Roztocze National Park. Pam. Puławski, 143: 195-2006.

Warcholińska A. U., 1998. Właściwości zagrożonych segetalnych roślin naczyniowych Polski. / Properties of threatened segetal vascular plants of Poland. Acta Univ. Lodz., Folia Bot. 13: 7-14.

Wnuk Z., Dy mon E., Grzebyk D. 1989. Zbiorowiska segetalne Rzeszowa. / Segetal communities of Rzeszów. Zesz.Nauk.AR w Krakowie, Rolnictwo, 28: 67-90.

Zi e m iń s k a - S m y k M., 2006. Zespoły segetalne w zbożach otuliny Roztoczańskiego Parku Narodowego. / Segetal associations in cereal crops of the buffer zone of the Roztocze National Park. Pam. Puł. 143: 207-218.

\section{Zbiorowiska roślinne pól uprawnych Skierbieszowskiego Parku Krajobrazowego}

\section{Streszczenie}

Badania florystyczne nad zbiorowiskami segetalnymi przeprowadzono w roku 2000 na polach uprawnych Skierbieszowskiego Parku Krajobrazowego. Na polach uprawnych Skierbieszowskiego Parku Krajobrazowego wyodrębniono 3 zespoły chwastów segetalnych w zbożach i 2 zespoły upraw okopowych. Na glebach brunatnych wytworzonych z lessów w zbożach występował powszechnie zespół Vicietum tetraspermae typicum. W tych samych warunkach siedliskowych wyróżniono w uprawach okopowych zespół Echinochloo-Setarietum. Największym bogactwem gatunkowym charakteryzowały się Consolido-Brometum oraz Lamio-Veronicetum politae, liczące średnio po około 25 gatunków w jednym zdjęciu. Fitocenozy te zajmowały niewielkie powierzchnie gleb rędzinowych badanego obszaru. Obydwa zespoły obfitowały w rzadkie gatunki segetalne, uważane za zagrożone w naszym kraju takie jak: Adonis aestivalis, Euphorbia exigua, Lathyrus tuberosus, Muscari comosum, Thlaspi perfoliatum, Veronica polita, Agrostemma githago. 